\title{
Cultural Studies and Philosophy: An Intervention
}

\author{
Douglas Kellner \\ (http://www.gseis.ucla.edu/faculty/kellner/kellner.html)
}

Since cultural studies has become a global popular in the past two decades, philosophy has been an unthematized and often suppressed dimension of the enterprise. While many trained in philosophy, such as myself, have engaged in the practice of cultural studies, few have reflected on the philosophical dimension and the role of philosophy within the project. The lack of reflection and debate over the function of philosophy within cultural studies and general suppression of such concerns have rendered cultural studies vulnerable to problematic philosophical positions and/or have vitiated the enterprise due to inadequately developed philosophical dimensions.

Accordingly, in this entry I will argue for three specific roles for philosophy in: 1) reflecting on the method, assumptions and metatheory of cultural studies; in articulating 2) the normative standpoint of critique and 3) in developing the moral and aesthetic dimension which are currently, in my opinion, not adequately at work in the dominant versions of cultural studies now circulating. Yet I do not want to exaggerate the importance of philosophy and my argument will be that cultural studies today should pursue its transdisciplinary project by combining philosophy, political economy, social theory, cultural critique, and a multiplicity of critical theories in the effort to develop a cultural studies adequate to the challenges of the present age.

\section{Conceptualizing Cultural Studies}

Cultural studies has today become a contested terrain with a variety of competing versions. In this fragmented and conflicted field, it is useful to sort out competing models and notions of cultural studies, to delineate their presuppositions, and to appraise the strengths and limitations of competing models. This is the job of metatheory which attempts to grasp the presuppositions of an enterprise, to critically analyze and appraise them, and to defend one's own perspective and position if one is advancing a substantive concept of one's own -- as I will do in this intervention.

While the diversity of cultural studies currently proliferating is vast, the movement that has been a global phenomenon of great importance over the last decade was inaugurated by the University of Birmingham Centre for Contemporary Cultural Studies in 1964, led at the time by Richard Hoggart and then by Stuart Hall from 1965-1979. Hence, our metatheoretical inquiries will begin with delineation of the presuppositions of British cultural studies during its initial period of gestation and development. During its now classical period, the Centre developed a variety of critical approaches for the analysis, interpretation, and criticism of cultural artifacts. Through a set of internal debates, and responding to social struggles and movements of the 1960s and the 1970s, the Birmingham group came to focus on the interplay of representations and ideologies of class, gender, race, ethnicity, and nationality in cultural texts, including media culture. They were among the first to study the effects of newspapers, radio, television, film, and other popular cultural forms on audiences. They focused on how various audiences interpreted and used media culture in varied and different ways and contexts, analyzing the factors that made audiences respond in contrasting ways to media texts. 
From the beginning, British cultural studies systematically rejected high/low culture distinctions and took seriously the artifacts of media culture, thus surpassing the elitism of dominant literary approaches to culture. Likewise, British cultural studies overcame the limitations of the Frankfurt School notion of a passive audience in their conceptions of an active audience that creates meanings and the popular. Building on semiotic conceptions developed by Umberto Eco, Stuart Hall argued that a distinction must be made between the encoding of media texts by producers and the decoding by consumers (1980b). This distinction highlighted the ability of audiences to produce their own readings and meanings, to decode texts in aberrant or oppositional ways, as well as the "preferred" ways in tune with the dominant ideology.

The now classical period of British cultural studies from the mid-1960s to the early $1980 \mathrm{~s}$ initially adopted a Marxian approach to the study of culture, one especially influenced by Althusser and Gramsci (see, especially Hall 1980a and Centre for Contemporary Cultural Studies 1980a and 1980b). Although members of the school of British cultural studies usually omit the Frankfurt school from the narrative of its genesis and history, some of the work done by the Birmingham group replicated certain classical positions of the Frankfurt school, in their social theory and methodological models for doing cultural studies, as well as in their political perspectives and strategies (see Kellner 1997b). Like the Frankfurt school, British cultural studies observed the integration of the working class and its decline of revolutionary consciousness, and studied the conditions of this catastrophe for the Marxian project of revolution. Like the Frankfurt school, British cultural studies concluded that mass culture was playing an important role in integrating the working class into existing capitalist societies and that a new consumer and media culture was forming a new mode of capitalist hegemony.

Both traditions focused on the intersections of culture and ideology and saw ideology critique as central to a critical cultural studies (Centre for Contemporary Cultural Studies 1980a and 1980b). Both saw culture as a mode of ideological reproduction and hegemony, in which cultural forms help to shape the modes of thought and behavior that induce individuals to adapt to the social conditions of capitalist societies. Both also interpreted culture as a potential form of resistance to capitalist society, as well as a mode of social reproduction, and both the earlier forerunners of British cultural studies, especially Raymond Williams (1958 and 1961), and the theorists of the Frankfurt school, conceived of high culture as forces of resistance to capitalist modernity. Later, British cultural studies would valorize resistant moments in media culture and audience interpretations and use of media artifacts, while the Frankfurt school tended, with some exceptions, to see mass culture as a homogeneous and potent form of ideological domination -- a difference that would seriously divide the two traditions.

Despite their differences, like the Frankfurt school, the work of the Birmingham school of cultural studies is transdisciplinary in terms of their metatheory and practice. It thus subverts existing academic boundaries by combining social theory, cultural analysis and critique, and politics in a project aimed at a comprehensive criticism of the present configuration of culture and society. Moreover, it attempts to link theory and practice in a project that is oriented toward fundamental social transformation.

Both traditions thus deployed theory as a mode of conceptualizing the general contours of the 
established mode of historical development and analyzed the conjunctions of culture and society in specific historical contexts. Max Horkheimer and T.W. Adorno's concept of the culture industry can be seen broadly as a philosophical analysis of the configuration of society and culture that was emerging in the era of state and monopoly capitalism in the 1930s and 1940s in Europe and the United States; the analyses of the decline of working class culture, the rise of a commercialized mass culture, and emergence of new oppositional cultures within British cultural studies can likewise be seen as a form of broad theoretical discourse often associated with philosophy -- or a philosophically-mediated social theory. Both schools, however, were resolutely historicist, seeing concepts and methods, as well as social forms, as developing in specific historical contexts and within specific modes of production. Both were influenced by Marxian modes of theorizing, though the Frankfurt School was more influenced by forms of Hegelian Marxism, such as had been developed by Lukacs and Korsch, whereas British cultural studies attempted to merge the historicist and activist perspectives of Gramsci with Althusser's more structuralist Marxism (see Hall 1980a).

From the beginning, British cultural studies was highly political in nature and focused on the potentials for resistance in oppositional subcultures, first, valorizing the potential of working class cultures, then, youth subcultures to resist the hegemonic forms of capitalist domination. Unlike the classical Frankfurt school (but similar to Herbert Marcuse), British cultural studies turned to youth cultures as providing potentially new forms of opposition and social change. Through studies of youth subcultures, British cultural studies demonstrated how culture came to constitute distinct forms of identity and group membership and appraised the oppositional potential of various youth subcultures (see Jefferson et al 1976 and Hebdige 1979). Cultural studies came to focus on how subcultural groups resist dominant forms of culture and identity, creating their own style and identities. People who conform to dominant dress and fashion codes, behavior, and political ideologies thus produce their identities within mainstream groups, as members of specific social groupings (such as white, middle-class conservative Americans). Individuals who identify with subcultures, like punk culture, or black nationalist subcultures, look and act differently from those in the mainstream, and thus create oppositional identities, defining themselves against standard models.

As it developed into the 1970s and 1980s, British cultural studies successively appropriated feminism, race theory, gay and lesbian theory, postmodern theory, and other fashionable theoretical modes. Thus, they turned to examining the ways that cultural texts promoted sexism, racism, homophobia, and other forms of oppression, or promoted resistance and struggle against these phenomena. This approach implicitly contained political critique of all cultural forms that promoted oppression and domination while positively valorizing texts and representations that produced a potentially more just and egalitarian social order.

With a postmodern turn in cultural studies, there was an increasing emphasis on the audience and how audiences produce meanings and how cultural texts produce both popular pleasures and forms of resistance (Ang 1985; Fiske 1989a, 1989b, and 1993). Critics of this phase of cultural studies claim that the project has been losing its critical edge, has fallen into a postmodern cultural populism (McGuigan 1992), and has surrendered the political radicalism and critical thrust of the original project (Kellner 1995). Defenders of the turn toward cultural populism argue that the original more critical model tended to be overly elitist and excessively critical of 
popular pleasures, while neglecting the complex ways that cultural texts can be appropriated and used.

The fetishism of the popular also leads dominant trends in British and North American cultural studies to slighting high culture and the engagement of modernist and avant garde movements, such as distinguished the work of the Frankfurt School whose analyses extended from the most esoteric modernist art to the most banal artifacts of media culture. It appears that in its anxiety to legitimate study of the popular and to engage the artifacts of media culture, cultural studies has turned away from so-called high or elite culture in favor of the popular. But such a turn sacrifices the possible insights into all forms of culture and replicates the bifurcation of the field of culture into a "popular" and "elite" (which merely inverts the positive/negative valorizations of the older high/low distinction). More important, it disconnects cultural studies from attempts to develop oppositional forms of culture of the sort associated with the "historical avant-garde" (Burger 1984). Avant-garde movements like Expressionism, Surrealism, and Dada wanted to develop art that would revolutionize society, that would provide alternatives to hegemonic forms of culture (see Bronner and Kellner 1983).

The oppositional and emancipatory potential of avant garde art movements was a primary emphasis of the Frankfurt School, especially Adorno and Walter Benjamin, and it is unfortunate that British and North American cultural studies have largely neglected engaging avant-garde art forms and movements. This is connected with a failure of many versions of cultural studies and the sociology of culture to develop philosophical perspectives on aesthetics as is found in the Frankfurt School. But the turn away from high culture, modernism, and aesthetics also points in British cultural studies to a failure to develop a radical cultural and media politics, such as is found in the works of Brecht and Benjamin, concerned with activist cultural politics and the development of alternative oppositional cultures. The ignoring of modernist and avant-garde art and intense focus on the popular was aided and abetted by the postmodern turn in cultural studies which disseminated key positions and strategies of British cultural studies throughout the world but also helped produce an important mutation in the cultural studies project.

In addition, I would argue that critical social theory is necessary to adequately develop cultural studies. Earlier models in the Frankfurt School and British cultural studies made the relationship between culture and society the center of their analysis, utilizing the methods of social theory and more literary and cultural analysis to contextualize the production, distribution and consumption of culture and to critically analyze cultural texts. As British cultural studies developed, it brought more and more theories into its purview, but as its project became globalized and absorbed into a multiplicity of disciplines the connection with social theory has often been attenuated. In some of the ludic, postmodern forms of cultural studies, context, text, and the constraints of everyday life disappear in descriptions of the pleasures of consumers or of the surfaces of texts. Thus, the relationship between cultural studies and social theory is itself complex, shifting, and variable.

In this context, I would propose that cultural studies utilize a synthesis of philosophy and critical social theory to develop a multiperspectivist approach which includes investigation of a broad expanse of artifacts, interrogating relationships within the three dimensions of: 1) the production and political economy of culture; 2) textual analysis and critique of its artifacts; and 3) study of 
audience reception and the uses of media/cultural products. This metatheory involves suggesting, first, that cultural studies itself be multiperspectivist, getting at culture from the optics of political economy and production, text analysis, and audience reception. I would also propose that textual analysis and audience reception studies utilize a multiplicity of perspectives, or critical methods, when engaging in textual analysis, and in delineating the multiplicity or subject positions, or perspectives, through which audiences appropriate culture. Moreover, the results of such studies need to be interpreted and contexualized within critical social theory to adequately delineate their meanings and effects.

Of course, there are dangers in championing the importance of the philosophical dimension in cultural studies. One of the hazards of cultural studies is the proclivity toward theoreticism, in which culture and society are reduced to discourse and in which one discourse is privileged above all others. This tendency leads to the problematic notion of a purely Baudrillardian, Foucaultian, Deleuzian, Habermasian, or (fill in the blanks) other form of cultural studies in which analysis is reduced to the problematics of the theorist in question. Of course, deploying any given theory in an imaginative way can yield novel and important insights. But reducing cultural studies to one theoretical problematic, or transcoding cultural studies into the language of a specific theory, can itself be highly destructive of the broader project.

One can obviously not deploy the full range of methods and perspectives noted above in each distinctive project that one undertakes and the nature of particular projects will determine what perspectives are most productive. But one should nonetheless see the dimensions of political economy, textual analysis, and audience research as complementing each other rather than as constituting separate domains. I am not, therefore, making the impossible suggestion that one adopt this comprehensive multiperspectivist approach every time that one sets out to do cultural studies or a piece of sociological cultural research. Obviously, intensely focusing on political economy, on audience reception, or on close textual reading and criticism, alone can be very valuable and yield important insights. But exclusively and constantly highlighting one of these dimensions to the omitting of others can be destructive for a sociology of culture or cultural studies that aims at developing comprehensive and inclusive approaches to culture and society, which interrogates culture in all of its dimensions.

\section{The Standpoint of Critique}

Hence, I would argue for metatheoretical perspectives within cultural studies to combine philosophy, critical social theory, political economy, and a variety of methods of textual analysis and audience study to capture the full wealth of the forms and effects of culture, ranging from high culture and modernism to media culture and oppositional subcultures. Philosophy would thus secure the metatheory of cultural studies, question and defend its assumptions, articulate its values, refine its concepts, and provide standpoints of critique -- topics that I will take up in this section.

A postmodern turn in cultural studies, however, has led to a surrender of articulation of a normative critical standpoint for cultural studies and has often substituted a predominately textualist or ludic approach for the earlier activist political thrust of cultural studies. The populist turn in audience reception has led to a sense that audiences alone produce meaning, that the 
polysemic overflow of cultural texts and diversity of audiences produces a multiplicity of meanings and effects that undermine attempts to provide privileged readings or to delineate audience response. Ludic textualism sees texts as polysemic proliferaters of meanings which elude hermeneutical delimitations. While it is true that indeterminacy of meaning in both texts and audiences undermine attempts to provide textual readings or analyses of effects that are anything more than provisional and probablistic, it is also true that extreme relativism is both disabling and itself problematic.

Stuart Hall's earlier theorizing of audience decoding stressed a "preferred reading" toward which the text attempts to direct its reader while acknowledging the possibility of negotiated, oppositional, and resistant readings (1980b). As David Morley points out, the concept of a preferred reading points to a structured polysemy, and concern with correspondences between texts and readings. Morley worries that the "new audience research" has gone too far toward relativism, romanticism of audience-decoding, indeterminancy of meaning, and occlusion of media power, and argues that cultural studies should return to a sociological materialism, a methodological pragmatism, and epistemological realism (1997: 122). His critique points to the need for philosophical perspectives to examine the various presuppositions of specific versions of cultural studies and to provide a standpoint for critique of textual idealism, extreme relativism, or ludic perspectives that merely celebrate textual pleasures and diverse audience readings to the exclusion of concern with meaning, truth, value, and other epistemological concerns.

I want, therefore, to articulate several standpoints of critique within cultural studies ranging from political to ethical and aesthetic critique. For the now classical period of the Birmingham school, political critique was privileged over other modes of cultural analysis and criticism. British cultural studies engaged the politics of representation, analyzing representations of class, gender, race, ethnicity, subculture, sexual preference, and nation. Especially in the late 1960s and into the 1970s, British cultural studies focused on critical dissection of the norms, values, role models, and negative and positive representations in cultural artifacts. Rather than focusing on ethics per se, British cultural studies and its later variants tended to engage the politics of representation. Employing Gramsci's model of hegemony and counterhegemony (see Gramsci 1971 and 1992), British cultural studies attempted to specify forces of domination and resistance in order to aid the process of political struggle and emancipation from oppression and domination. Their politics of representation thus entailed a critique of cultural representations that promoted racism, sexism, classism, or any forms of oppression. Representations that promoted domination and oppression were thus negatively valorized, while those that promoted egalitarianism, social justice, and emancipation were positively valorized.

In this optic, ethics tends to be subordinated to politics and the moral dimension of culture tends to be underemphasized or downplayed. Thus, one could argue for a cultural studies that more explicitly stresses the importance of ethical/moral analysis, scrutinizing cultural texts for the distinctive ethical norms, ideals, and values portrayed and then evaluating the work accordingly. Or one could explore in more detail and depth than is usually done in cultural studies the moral and philosophical dimensions of cultural texts, the ways that they carry out moral critiques of society and culture, or embody moral concerns regarding good and evil, and right and wrong, while constructing -- or deconstructing! -- models of moral and immoral behavior or phenomena. 
I have used the terms "ethics" and "moral" in the preceding paragraph and for the purposes of this discussion I would like to distinguish between "ethics" and its cognates and "morality" and its family of terms. In ethical analysis, one is concerned with norms, values, models, and what Hegel called Sittlichkeit, the established ethical discourses and practices of a given society. Morality, by contrast, concerns ideals of the good and the ought which terminate in imperatives, articulating that realm described by Kant as Moralität. Within cultural studies, then, ethical analysis and critique dissects the norms, values, and societal models embedded in specific cultural representations, discourses, and texts which are subjected to critical scrutiny in the light of specific moral, political, or aesthetic values.

I am not advocating, however, moralistic critique of culture in which one condemns certain representations, texts, or even genres (i.e. pornography) as "immoral" or harmful in some way. What I am calling for is critical dissection of the ethical and moral discourses and effects of specific texts, carrying out spirited discussion of the norms, moral and otherwise, in which we critically analyze and perhaps judge specific cultural texts or artifacts. I am thus against moral dogmatism and absolutism, but am concerned to promote discussion of representations of ethical phenomena in cultural studies and the norms and ideals of moral critique.

Indeed, ethical concerns permeated earlier versions of cultural studies (see Hoggart 1957 and Williams 1958). Culture is, among other things, a major transmitter and generator of values and a cultural studies sensitive to the very nature and function of culture should be aware of its ethical and moral dimension. Thus, concern with ethics and with how cultural texts transmit specific ethical values and moral ideals should be a central and fundamental consideration of cultural studies, as it was with classical literary studies. While it is unlikely that the texts of media culture have the ethical/moral depth and complexity of great literary texts, it is clear that ethical and moral concerns are of fundamental importance to the sort of popular cultural artifacts that have been the domain of cultural studies.

Likewise, it is important to raise the issue of ethical and moral judgment and critique in order to engage in critical discuss of what precise values, norms, and ideals are not only represented in cultural texts, but are also operative in the specific work of cultural studies itself. Raising the issue of the ethical and moral dimension of cultural studies obviously brings up the issues of what values one uses and justifies in doing cultural critique. That is, while a merely descriptive account of ethical values in cultural texts does not commit one to specific moral positions, if one criticizes media culture for ethical or moral failures -- i.e. depicting excessive sex and violence, propagating pornography, prejudicial representations of women or people of color, glorifying war, etc. -- then one needs to justify one's critical standpoint. This issue, of course, opens the door for passionate philosophical disputation and I think that the absence of such vigorous ethical and philosophical debate within cultural studies has vitiated the project. Although one wants to avoid ethical absolutism and dogmatism, it strikes me as healthy to discuss precisely what ethical values are being deploying in carrying out critiques of artifacts of media culture. It also strikes me as salutary to force those making ethical judgments to defend their values and presuppositions, making clear why they are advancing such judgments.

If philosophical argumentation involves putting in question presuppositions and assumptions, giving reasons for one's position, engaging in critical dialogue, then such discourse, I believe, 
would only strengthen cultural studies, providing more robust interpretations and debates. The relative neglect of ethical-moral critique and disputation is another symptom, then, of the avoidance of hard philosophical issues in dominant versions of cultural studies, a neglect that I believe undermines the project.

As noted above, British cultural studies has also tended to eliminate aesthetics concerns from its project -- a move that I suggested above was both theoretically and politically disabling. British cultural studies never really theorized à la Frankfurt School the contradictions of culture, i.e. that culture is an ordinary part of everyday life, of social reproduction --, but also transcendent, constituting another dimension that can serve as a locus of critique and opposition. British cultural studies has either focused on culture and cultural experience as a means of reproducing or opposing the existing society and on the latter has tended to ignore the possibilities of art as transcendence, especially the ways that certain art forms can produce critical visions of existing reality or alternative representations of a better world. The neglect of aesthetics in cultural studies leaves out the transcendent dimension of culture, of culture that surpasses ordinary experience and everyday life, of art that presents visions of another world and alternative modes of thought and being. Likewise, British cultural studies tends to ignore the potential shock effects of aesthetic modernism and the avant-garde, the ways that art can shake up ordinary modes of perception, awaken individuals to perceive ugly or frightening realities often suppressed.

A dialectics of culture such as is found in the works of Adorno, Benjamin, or Marcuse sees culture as both affirmative and negative, as both reproducing and opposing the established social reality. Thus, while on one hand culture is ordinary, constituting shared common experiences of familiar modes of everyday life, on the other hand, culture is extraordinary, providing another dimension to existing reality, one of transcendence, autonomy, and potential opposition. Culture can generate meanings that help transform life as well as idealizing and stabilizing existing forms. It can help shape subcultures of resistance and provide critical perspectives on existing reality that provide an impetus to personal or social transformation. Art, is its manifold guises and forms, is important and should not be neglected by cultural studies.

Yet aesthetic critique and opposition has its limitations and I do not want to propose a wholesale aestheticizing of cultural studies, although I believe critically taking up issues of aesthetics can strengthen the enterprise. The initial distancing from aesthetics within British cultural studies probably had to do with a desire to renounce the idealism and elitism of many aesthetic approaches; British cultural studies emerged as an overcoming of the textualism and aestheticism of literary analysis, but in reacting against its excesses, I would argue, went too far in throwing issues of aesthetics out of cultural studies altogether.

With the postmodern turn in culture, in which aesthetics becomes a more salient aspect of every domain of life from packaging and advertising of commodities to the creation of identity and life-style, one needs to realize that aesthetics are a key ingredient of everyday life and require serious scrutiny. Of course, the absorption of aesthetics into everyday life renders claims for a critical and transcendent dimension of culture problematic -- as Jameson argues in his famous article on postmodernism (1991: 47ff). Yet precisely the question of what forms of art do and do not have critical and oppositional potential, as well as questions of the intersection of art and politics, and of aesthetics and everyday life, continue to be relevant and important to the project 
of understanding and transforming existing societies and cultures. Thus, I would argue that concerns with aesthetics should be an important part of a revitalized cultural studies for the next millennium.

\section{Cultural Studies, Pedagogy, and Politics: Some Concluding Comments}

A critical cultural studies would thus pursue certain aesthetic, ethical, and political ends. Yet understanding the origins, locations, and effects of cultural studies also involves a concern with pedagogy. While the early development of British cultural studies was closely connected to adult education and pedagogy, later cultural studies became more academic and disciplinary. In recent years, however, there has been a call to return cultural studies to articulation with a critical pedagogy, a project that I endorse (see Giroux 1994; Grossberg 1997; and Kellner 1995). Since media culture itself is a potent form of pedagogy, cultural studies should develop a counterpedagogy that teaches audience how to read cultural texts, how to critically decode and produce oppositional readings, and thus to understand the effectivity of cultural texts in socialization, the construction of identity, and the reproduction of social relations.

Questions of pedagogy inevitably involve questions of value, thus the political, ethical, and aesthetic concerns I discussed above would be a key aspect of a pedagogy of cultural studies. I would also argue that critical pedagogy involves what Paolo Freire (1973 and 1998) calls reading the world through reading the text, so that gaining critical literacy, the ability to read the word, involves at the same time learning to read the world through the word and text. This injunction is parallel to a basic tenet of critical cultural studies that operates with a dialectic of text and context, situating and reading texts through their social contexts and better understanding context through critical reading of texts. From this perspective, gaining critical media literacy involves learning to read texts through the world and the world through texts. Hence, just as politics is a form of pedagogy, a critical pedagogy is a form of politics, teaching individuals how to situate their forms of culture and their everyday lives in the context of the social and political system in which they live.

Developing critical media literacy also requires development of a postmodern pedagogy that takes seriously image, spectacle, and narrative, and thus promotes visual and media literacy, the ability to read and analyze critically images, stories, and spectacles of media culture. Yet a postmodern pedagogy is concerned to develop multiple literacies, to rethink literacy itself in relation to new technologies and new cultural forms, and to develop a cultural studies that encompasses a wide array of fields, texts, and practices, extending from popular music to poetry and painting to cyberspace and multimedia like CD-ROMs (see Kellner 1998 and Hammer and Kellner 1999).

The particular pedagogy employed, however, should be contextual, depending on the concrete situation, interests, and problems within the specific site in which cultural studies is taught or carried out. For it will be the distinctive interests of the teachers, students, or critic that will help determine what precise artifacts are engaged, what methods will be used, and what pedagogy will be deployed. Just as a cultural studies research problem and text is necessarily contextual, flexible, and open-ended, so too must be its pedagogy and its politics. 
Such a transdisciplinary and political project involves a synthesis of the Frankfurt school, British cultural studies, postmodern theory, and other critical approaches, combining empirical research, theory, critique, and practice. A revitalized cultural studies would reject the distinction between high and low culture and would study a broad expanse of cultural artifacts. It would use the concept of an active audience and valorize resistance, but also explore manipulation and more passive reception, detecting both the ruses of media power and the tactics of audience resistance. A political cultural studies would follow earlier trends of British cultural studies with detailed consideration of oppositional subcultures and alternatives to mainstream culture, but would also devise strategies of developing alternative media and an activist cultural politics. It would combine the Frankfurt School focus on political economy, on media manipulation, and on the ways that culture reproduces domination, with scrutiny of the emancipatory potential of a wide range of cultural artifacts extending from modernism and the avant garde to critical and subversive moments in media culture.

A critical sociology of culture and oppositional cultural studies would also draw upon feminist approaches and multicultural theories to fully analyze the functions of gender, class, race, ethnicity, nationality, sexual preference, and so on which are so important in constituting cultural texts and their effects, as well as being fundamentally constitutive of audiences who appropriate and use texts. British cultural studies progressively adopted a feminist dimension (see McRobbie 1994 and 1997; and Gray 1997) and paid greater attention to race, ethnicity, and nationality, and sexuality, as various discourse of race, gender, sex, nationality, and so on circulated in responses to social struggles and movements. Earlier forms of cultural studies sought to articulate analysis of the thematics and effects of its artifacts with existing political struggles and I would defend returning to this project. There indeed continues to be a significant number of attempts to connect cultural studies with oppositional political movements and, more recently, with more pragmatic involvement in policy issues and debates (see McGuigan 1996 and Bennett 1992 and 1997). There are thus a heterogeneity of political articulations of cultural studies and, as with its pedagogy, its politics will necessarily be conjunctural and contextual, depending on the particular site and moment of a certain form of cultural studies.

Moreover, it is of crucial importance for a theoretically responsible cultural studies to continually appropriate the latest theoretical discourses and to modify its assumptions, program, and discourses in response to critiques of its previous work, the emergence of new theories that can be used to strengthen one's future work, and in response to oppositional social movements which produce novel critical political discourses and practices. Both the Frankfurt school and British cultural studies continually modified their work in response to new theoretical and historical developments and in a period of rapid social-historical change and the proliferation of new theories, cultural practices, and forms of political struggle, engagement with theory and history is of fundamental importance for cultural studies today.

To capture the novelties of the present moment, bold vision is needed. Adorno and Horkheimer's critique of the culture industry, for example, provides a provocative philosophical overview of the production, nature, circulation, and reception of products of the culture industry as it had developed into the 1940s (1972 [1947]). Fredric Jameson's magistral sketch of the contours of postmodernism provides a highly suggestive mapping of contemporary culture that has generated a wealth of debate and insight (1984 and 1991). Technological revolution and the emergence of 
new forms of cyberculture, new identities, new public spheres, and new politics require similar daring philosophical vision today.

Hence, a contemporary cultural studies would be open to new theoretical impulses and would be prepared to engage new subject matter. We are currently living in a proliferating image culture in which new technologies are changing every dimension of life from the economy to personal identity. In a postmodern media and computer culture, fresh critical strategies are needed to read narratives, to interpret the conjunctions of sight and sound, words and images, that are producing novel cultural spaces, forms, and experiences. This project also involves exploration of the emergent cyberspaces and modes of identities, interaction, and production that is taking place in the rapidly exploding computer culture, as well as exploring the new public spaces where myriad forms of political debate and struggle are evolving (Kellner 1997c). Finally, a future-oriented sociology of culture should look closely at the development of the media and computer industries, the mergers and synergies taking place, and the syntheses of information and entertainment, computer and media culture, that are being planned and already implemented. A global media and cyberculture is our life world and fate and we need to be able to chart and map it accordingly to survive the dramatic changes currently taking place and the even more transformative novelties of the rapidly approaching future.

\section{$\underline{\text { References }}$}

Ang, Ien (1985)

(1991) Desperately Seeking the Audience. London and New York: Routledge.

(1996). Living Room Wars. Rethinking Audiences for A Postmodern World. London and New York: Routledge.

Agger, Ben (1992) Cultural Studies. London: Falmer Press.

Aronowitz, Stanley (1993) Roll Over Beethoven. Hanover, New Hampshire: University Press of New England.

Benjamin, Walter (1969) Illuminations. New York: Shocken.

Bennett, Tony (1982) "Theories of the Media, Theories of Society," in Gurevitch, et al, Culture, Society, and the Media. London: Macmillan.

(1992) "Putting the Policy into Cultural Studies," in Grossberg, et al 1992.

61.

"Towards a Pragmatics for Cultural Studies," in McGuigan 1997b: 42-

Best, Steven and Douglas Kellner (1991) Postmodern Theory: Critical Interrogations. London and New York: Macmillan and Guilford Press. 
(1997) The Postmodern Turn. New York: Guilford Press.

(forthcoming) The Postmodern Adventure. New York: Guilford Press.

Blundell, et al (1993) Relocating Cultural Studies. New York: Routledge.

Bronner, Stephen and Kellner, Douglas eds (1983) Passion and Rebellion: The Expressionist Heritage. Universe Books and Bergin Publishers (USA) and Croom Helm (England); second edition, Columbia University Press 1988.

York: Routledge.

(1989) Critical Theory and Society. A Reader. New

Bürger, Peter (1984 [1974]) Theory of the Avant-Garde. Minneapolis: University of Minnesota Press.

Centre for Contemporary Cultural Studies (1980a) On Ideology London: Hutchinson.

(1980b) Culture, Media, Language. London: Hutchinson.

Davies, Ioan (1995) Cultural Studies, and After. London and New York: Routledge.

During, Simon (1993) ed. The Cultural Studies Reader. London and New York: Routledge (second edition 1998).

Dworkin, Dennis (1997) Cultural Marxism in Postwar Britain: History, the New Left, and the Origins of Cultural Studies. Durham: Duke University Press.

Fiske, John (1989a) Reading the Popular. Boston: Unwin Hyman.

(1989b) Understanding Popular Culture. Boston: Unwin Hyman.

(1990) Introduction to Cultural Studies. London: Routledge.

(1993) Power Plays. Power Works. New York and London: Verso.

Freire, Paulo (1972) Pedagogy of the Oppressed. New York: Herder and Herder.

Freire, Paulo (1998) The Paulo Freire Reader. New York: Continuum.

Giroux, Henry (1994) Distrubing Pleasures. Learning Popular Culture. London and New York: Routledge.

Gramsci, Antonio (1971) Selections from the Prison Notebooks New York: International Publishers. 
(1992) Prison Notebooks. Volume 1. New York: Columbia University Press.

Grossberg, Lawrence (1997) Dancing in Spite of Myself. Essays on Popular Culture. Durham and London: Duke University Press.

Grossberg, Lawrence, Nelson, Cary and Paula Treichler (1992) Cultural Studies. New York: Routledge.

Hall, Stuart, et al (1980) Culture, Media, Language. London: Hutchinson.

Hall, Stuart (1980a) "Cultural Studies and the Centre: Some problematics and problems," in Hall et al, 1980, 15-47.

(1980b) "Encoding/Decoding," in Hall et al, 1980, 128-138.

Hammer, Rhonda and Douglas Kellner (1999) "Multimedia Pedagogical Curriculum for the New Millennium," Journal of Adolescent \& Adult Literacy, Vol. 42, Nr. 7 (April): 522-526; longer version forthcoming in Journal of Religious Education, 1999.

Hebdige, Dick (1978) Subculture. The Meaning of Style. London: Methuen.

Hoggart, Richard (1957) The Uses of Literacy. New York: Oxford University Press.

Horkheimer, Max and T.W. Adorno (1972) Dialectic of Enlightenment. New York: Seabury.

Jameson, Fredric (1991) Postmodernism, or the Cultural Logic of Late Capitalism. Durham, N.C.: Duke University Press.

Jefferson, Tony et al. (1976) Reistance through Rituals. London: Hutchinson.

Jensen, Joli and Pauly, John J. (1997) "Imagining the Audience: Losses and Gains in Cultural Studies," in Ferguson and Golding 1997: 155-169.

Johnson, Richard (1986/87) "What is Cultural Studies Anyway?" Social Text 16: 38-80.

Kellner, Douglas s (1992) "Toward a Multiperspectival Cultural Studies," Centennial Review, Vol. XXVI, No. 1 (Winter): 5-42.

(1995) Media Culture. Cultural Studies, Identity, and Politics Between the Modern and the Postmodern. London and New York: Routledge.

(1997a) "Overcoming the Divide: Cultural Studies and Political Economy" in Ferguson and Golding 1997: 102-119.

(1997b) "Critical Theory and British Cultural Studies: The Missed 
Articulation," in McGuigan 1997b: 12-41.

(1997c)" Intellectuals, the New Public Spheres, and Technopolitics," New Political Science \#41-42: 169-188.

(1998) "Multiple Literacies and Critical Pedagogy in a Multicultural Society." Educational Theory, Vol. 48, Nr. 1: 103-122.

Mepham, John (1991) "Television Fiction-- Quality and Truth-Telling," Radical Philosophy 57 (Spring): 20-27.

McGuigan, Jim (1992) Cultural Populism. London and New York: Routledge.

(1997a) "Cultural Populism Revisited" in Ferguson and Golding 1997: 138-154.

(1997b), ed. Cultural Methodologies. London: Sage.

McRobbie, Angela (1994) Postmodernism and Popular Culture. London and New York: Routledge.

(1997) "The Es and the Anti-Es: New Questions for Feminism and Cultural Studies," in Ferguson and Golding 1997: 170-186.

Morley, Davide (1992) Television, Audiences, and Cultural Studies. New York and London: Routledge.

(1997) "Theoretical Orthodoxies: Textualism, Constructivism and the 'New Ethnography' in Cultural Studies," in Ferguson and Golding 1997: 121-137.

O'Connor, Alan (1989) "The Problem of American Cultural Studies," Critical Studies in Mass Communication (December), 405-413.

Steele, Tom (1997) The Emergence of Cultural Studies 1945-65: Adult education, Cultural Politics and the English Question. London: Lawrence \& Wishart.

Stevenson, Nick (1997) "Towards a Pragmatics for Cultural Studies," in McGuigan 1997b: 6286.

Tester, Keith (1994) Media, Culture and Morality. New York and London: Routledge.

Turner, Graeme (1990) British Cultural Studies: An Introduction. New York: Unwin Hyman.

Williams, Raymond (1958) Culture and Society. New York: Columbia University Press. (1961) The Long Revolution. London: Chatto and Windus. 
(1976) Keywords. New York: Oxford University Press.

(1981) Communications. London: Penquin.

Notes 